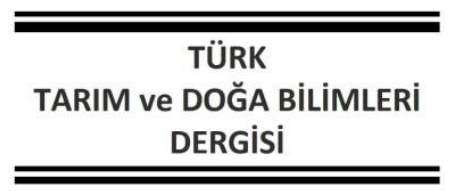

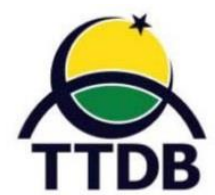

www.dergipark.gov.tr/turkjans

Araştırma Makalesi

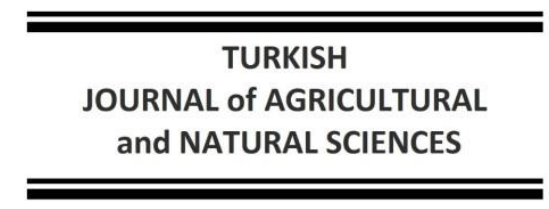

and NATURAL SCIENCES

\title{
Buğday Üreticilerinin Risk ve Risk Stratejileri Algısı: Kahramanmaraş ili Örneği
}

\author{
Hasan Burak AĞIR ${ }^{1 *}$, Melih ERDEM ${ }^{1}$
}

${ }^{1}$ Kahramanmaraş Sütçü İmam Üniversitesi, Ziraat Fakültesi, Tarım Ekonomisi Bölümü, Kahramanmaraş

*Sorumlu Yazar: hburakagir@ksu.edu.tr

Geliş Tarihi: 26.10.2021 Düzeltme Geliş Tarihi: 20.12.2021 Kabul Tarihi: 13.01.2022

\section{Öz}

Bu çalışmada Kahramanmaraş illinde buğday üretimi yapan üreticilerin üretim sürecinde karşılaştıkları riskler ve bu risklere karşı uyguladıkları stratejilerin belirlenmesi amaçlanmıştır. Bununla birlikte belirlenen risk faktörlerinin üreticilerin gelirine etkisi ve risk stratejilerinin üreticilerin sosyo-demografik özellikleri ile ilişkisi ortaya konulmuştur. Çalışmanın ana materyalini 2019 yılında Kahramanmaraş’ta buğday üretimi yapan 120 üretici ile yüz yüze yapılan anketler oluşturmaktadır. Çalışmanın amaçları doğrultusunda öncelikle açıklayıcı faktör analizi yapılmıştır. Faktör analizinden elde edilen değişkenler çoklu regresyon analizinde kullanılmıştır. Elde edilen sonuçlara göre üreticilerin en çok karşılaştığı riskler; üretim ve teknik risklerdir. Regresyon analizi sonucuna göre finansal $(p<0.10)$ ve iklim $(p<0.05)$ risklerinin üretici gelirine negatif yönlü etki yaptığı belirlenmiştir. Bunun yanında üreticilerin uyguladıkları risk stratejileri ile gelir, tecrübe, tarım dışı gelir, tarımsal örgütlere üyelik durumu ve finansal riskler gibi risk faktörleri arasındaki ilişkinin anlamlı olduğu saptanmıştır. Bu bağlamda, politika yapıcıların finansal risklerin üretim üzerindeki etkisini azaltmak için tarımsal destek ve kredi miktarını artırması ve bu kaynaklara ulaşımı daha kolay hale getirmesi önemlidir. Bununla birlikte iklim risklerine karşı ise üreticilerin tarım sigortası (bitkisel üretim sigortası ve köy bazlı kuraklık sigortası) konusunda bilinçlendirilmesi ve teşvik edilmesi gerekmektedir.

Anahtar kelimeler: Buğday üretimi, risk faktörleri, risk stratejileri

\section{Perception of Wheat Farmers' Risk and Risk Strategies: The Case of Kahramanmaraş Province}

\begin{abstract}
The study aims to determine the risk factors faced by the wheat farmers and farmers' risk strategies against these risk factors in Kahramanmaraş province. Also, the effect of perceived risk factors on farmers' income and relationship with sociodemographic characteristics of farmers and their risk strategies were revealed. The main material was obtained from 120 farmers in Kahramanmaraş in 2019. First, factor analysis was employed to classify the risk sources and risk strategies. Then, multiple regression analysis was used to examine the effect of risk factors on farmers' income and the relationship between socio-demographic characteristics of farmers and risk strategies. According to the results, farmers percieved production and technical risks more strongly. The regression analysis showed that the financial $(p<0.10)$ and climate $(p<; 0.05)$ risks had a negative effect on farmers' income. Besides, there was a relationship between perceived risk strategies and income, experience, non-agricultural income, membership status and financial risk factors. In this context, policymakers should increase the agricultural supports and credits, and make access to these resources easier to reduce the negative effect of financial risks on production. Also, it is important to raise awareness and encourage the farmers about agricultural insurance (crop insurance and village-based drought insurance) against climate risks.
\end{abstract}




\section{Giriş}

Birçok sektöre ham madde sağlayan tarımsal üretim, çeşitli risk ve belirsizliklerle karşı karşıyadır. Risk, genel olarak tarımsal üretimde yapılan planların gerçekleşmeme intimali olarak ifade edilmektedir (Bayramoğlu ve ark., 2013). Tarımsal üretimde; üretim, pazarlama, finansman, teknoloji, politika ve iklim koşulları başlıca risk faktörleridir. Bu riskler sonucunda ürün verimi, fiyat ve tarımsal gelirde yıldan yıla ciddi farklılıklar yaşanmaktadır (Vuruş Akçaöz ve Akdemir, 2001).

Riskin etkisini düşürmek, riski azaltmak veya olumsuz durumlarda işletmenin üretimini devam ettirebilmesi için bazı önlemlerin alınması gerekmektedir. Bu önlemlerin işletme yapısına ve yöneticisine bağlı olarak, işletme amaçlarına ve finans durumuna uygun şekilde belirlenmesi önemlidir. Tarımsal üretim risk altında gerçekleştirilemeyeceği gibi riski tamamen yok etmek de mümkün değildir. Ancak riskler karşısında uygulanan çeşitli stratejilerle ortaya çıkacak problemler transfer edilebilir, kontrol altına alınabilir veya etkisi azaltılabilir (Vuruş Akçaöz ve Özkan, 2002).

Türkiye'de çiftçilerin üretim sürecinde doğru tercihte bulunmaları, karşılaşılan risklerin analiz edilerek uygun risk stratejilerinin geliştirilmesine bağlı olmakla birlikte üreticinin bu risklere karşı davranışlarının analiz edilip önerilerin geliştirilmesi ve uygulanması gerekmektedir (Hazneci ve Ceyhan, 2011). Risklerin net bir şekilde belirlenmesi, bu risklerle karşılaşıldığında önlem alınmasını oldukça kolaylaştıracaktır (ikikat Tümer ve ark., 2010).

Literatürde tarımsal üretimde risk ve risk stratejilerini ortaya koymak için bitkisel ve hayvansal üretim faaliyetlerine yönelik çeşitli çalışmalar bulunmaktadır (Vuruş Akçaöz ve Akdemir, 2001; Vuruş Akçaöz ve Özkan, 2002; Özsayın ve Çetin, 2004; Akçaöz ve ark., 2006; Ikikat Tümer ve ark. 2010; Hazneci ve Ceyhan, 2011; Aditto ve ark., 2012;; Theuvsen, 2013; Bayramoğlu ve ark., 2013; Naseri ve Saner, 2017; İkikat Tümer ve ark., 2019; Hayran, 2019; Uçar ve Engindeniz, 2019).

Literatürdeki

çalışmalar değerlendirildiğinde, çalışmaların genellikle risk kaynakları ve stratejilerinin belirlenmesi ve bunlar ile sosyo-demografik özellikler arasındaki ilişkinin ortaya konulması şeklinde olduğu görülmektedir. $\mathrm{Bu}$ çalışmanın risk faktörlerinin üretici gelirine etkisini analiz edecek olması araştırmanın önemini ortaya koymaktadır. Ayrıca konu ile ilgili Kahramanmaraş ilinde yapılan herhangi bir araştırma olmaması da çalışmanın önemini bir kat daha artırmaktadır. Bu doğrultuda bu çalışmada
Kahramanmaraş ilinde buğday üreticilerinin üretimde karşılaştıkları riskler ve uyguladıkları stratejilerin belirlenmesi amaçlanmıştır. Bununla birlikte belirlenen risk faktörlerinin buğday gelirine etkisi ve üreticilerin bazı sosyo-demografik özellikleri ile risk stratejileri arasındaki ilişki ortaya konmuştur.

\section{Materyal ve Metot}

Çalışmanın ana materyalini 2019 yılında Kahramanmaraş ili merkez ilçelerinde (Onikişubat ve Dulkadiroğlu) buğday üretimi yapan toplam 120 üretici ile yapılan anketlerden elde edilen veriler oluşturmaktadır. Ayrıca konu kapsamındaki tez, makale ve çeşitli istatistiksel raporlar gibi ikincil kaynaklardan da yararlanılmıştır.

Araştırma bölgesinde toplam 3548 adet buğday üreticisi olduğu saptanmıştır. Örnek hacminin belirlenmesinde oransal örnek hacmi formülü kullanılmıştır (Newbold, 1995). Çalışmada \%95 güven aralığında ve \%10 hata payı ile anket yapılacak üretici sayısı 120 olarak belirlenmiştir.

$$
n=\frac{N p(1-p)}{(N-1) \sigma_{p_{x}}^{2}+p(p-1)}
$$

Formülde;

$\mathrm{n}$ : Örnek büyüklüğü,

$\mathrm{N}$ : Popülasyondaki üretici sayısı,

p: Buğday üretimi yapan işletmelerin

popülasyondaki oranı (maksimum örnek hacmi için 0.5 alınmıştır)

r: Ortalamadan izin verilen hata payı (\%10),

$Z_{\alpha / 2}$ : z cetvel değeri $(1,96)$,

$\sigma_{p_{x}}^{2}$ : Oranın varyansı,

$$
\sigma_{p_{x}}^{2}=\left(\frac{r}{Z_{\alpha / 2}}\right)^{2}=\left(\frac{0.10}{1.96}\right)^{2}=0.00260
$$

Üreticilerin risk ve risk stratejilerine karşı tutumlarını belirlemek için 5'li likert ölçeği, sosyodemografik özelliklerin belirlenmesinde ise tanımlayıcı istatistikler kullanılmıştır. Üreticilerin karşılaştıkları risk faktörlerinin belirlenmesi ve bu faktörlere karşı uyguladıkları risk stratejilerinin ortaya konması için faktör analizi kullanılmıştır. Faktör analizi çalışmalarda verilerin sayısını azaltmak, daha kısa ve açıklayıcı duruma getirmek amacıyla kullanılmaktadır. Faktör analizinde faktörlerin belirlenmesini sağlayan birçok teknik bulunmaktadır. Bu çalışmada Temel Bileşenler Analizi (Principal Component Analysis-PCA) tekniği kullanılmıştır. Bu teknikte, arasında yüksek korelasyon bulunan değişkenler arasındaki en yüksek varyansı sağlayan birinci faktör 
belirlenmektedir. Aynı yöntem uygulanarak kalan değişkenlerde en yüksek varyansı oluşturan ikinci faktör belirlenmektedir. Bu durum son faktör belirlenene kadar devam etmektedir. Burada önemli olan elde edilen faktörler arasında herhangi bir korelasyonun olmamasıdır (Büyüköztürk, 2002). $\mathrm{Bu}$ çalışmada faktör analizinde kullanılan verilerin güvenirliliği test etmek amacıyla Cronbach's Alpha katsayısından yararlanılmıştır. Aynı zamanda verilerin faktör analizine uygunluğunu belirlemek için Kaiser-Meyer-Olkin değeri ve Bartlett's testi kullanılmıştır (Çolakoğlu ve Büyükekşi, 2014).

Faktör analizi sonucunda elde edilen risk faktörlerinin buğday verimi üzerindeki etkisini ve risk stratejilerini etkileyen sosyo-demografik değişkenleri belirlemek amacıyla çoklu regresyon analizinden yararlanılmıştır. Çoklu regresyon analizi, bağımlı değişken ile bir ya da birden çok bağımsız değişken arasındaki ilişkinin belirlenmesi için kullanılan bir yöntemdir. Bu çalışmada faktör analizinden elde edilen risk faktörlerinin buğday gelirine etkisi ile risk stratejileri ve üreticilerin sosyo-demografik özellikleri kullanılarak oluşturulan modeller aşağıda verilmiştir.

Model 1'de bağımlı değişken olan BG üreticilerin buğday üretiminden elde ettikleri geliri ifade etmektedir. $b_{0}$ modelin sabit terimi, $b_{1}, b_{2}, b_{3}$, $b_{4}, b_{5}$ ise risk faktörlerinin regresyon katsayılarıdır. Modelde faktör analizinden elde edilen FR (finansal riskler), PAR (pazarlama ve altyapı riskleri), ÜTR (üretim ve teknik riskler), DVMR (düşük verim ve maliyet riskleri), IR (iklim riskleri) bağımsız değişkenler olarak kullanılmıştır.

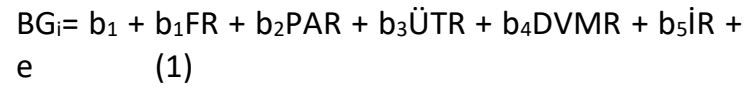

Model 2'de ise RS i, faktör analizi sonucunda belirlenen risk stratejilerini ifade etmektedir. bo, regresyon sabitini gösterirken, $b_{1}, b_{2}, b_{3}, b_{4}, b_{5}, b_{6}$ ve $b_{7}$ ifadeleri üreticilerin sosyo-demografik özelliklerinin regresyon katsayılarını belirtmektedir. $b_{8}, b_{9}, b_{10}, b_{11}, b_{12}$ ise risk faktörlerinin regresyon kat sayılarını göstermektedir. Modelde kullanılan bağımsız değişkenler; LYG (log-yıllık gelir), LM (logmesafe), LT (log-tecrübe), TDG (tarım dışı gelir), TÖÜ (tarımsal örgüte üyelik), ABS (ailedeki birey sayısı), IB (işletme büyüklüğü), FR (finansal riskler), PAR (pazarlama ve altyapı riskleri), ÜTR (üretim ve teknik riskler), DVMR (düşük verim ve maliyet riskleri), IR (iklim riskleri) şeklindedir.

$R S_{i}=b_{0}+b_{1} L Y G+b_{2} L M+b_{3} L T+b_{4} T D G+b_{5} T O ̈ U ̈+$ $b_{6} A B S+b_{7} i B+b_{8} F R+b_{9} P A R+b_{10} D V M R+b_{11} i R+$ $b_{12}$ ÜTR + e

\section{Bulgular ve Tartışma}

Çalışmada buğday üretimini etkileyen risk kaynakları bölgenin tarımsal ve sosyo-ekonomik şartları ve konu ile ilgili literatür göz önünde bulundurularak 22 başlık altında değerlendirilmiştir.

Kullanılan veri setinin faktör analizine uygunluğunu tespit etmek için Kaiser-Meyer-Olkin (KMO) ve Barlett testi uygulanmıştır. KMO değeri 0.73 olup, bu değer veri setinin faktör analizinde kullanılması için uygun olduğunu göstermektedir. Aynı zamanda Barlett testi de istatistiki açıdan anlamlı bulunmuştur ( $p=0.000)$. Risk kaynaklarının güvenirliğini ölçmek için kullanılan Cronbach's Alpha testi sonuçlarına göre katsayı 0.78 olarak hesaplanmıştır. Buna göre analizde kullanılan ölçek güvenlidir (Çizelge 1).

Araştırma alanı ve üretim koşulları dikkate alınarak belirlenen 22 adet risk kaynağı, yapılan faktör analizi sonucunda 5 faktör altında toplanmıştır. Elde edilen beş faktör toplam varyansın \%72.27'sini açıklamaktadır (Çizelge 1).

Risk kaynaklarının faktör yükleri dikkate alınarak 5 faktör belirlenmiştir. Bunlar "Üretim ve Teknik Riskler", "Finansal Riskler", "Düşük Verim ve Maliyet Riskleri", "Pazarlama ve Altyapı Riskleri" ve "iklim Riskleri" olarak isimlendirilmiştir. Hayran (2019) Bitlis ilinde yaptığı çalışmada buğday üretimini en çok etkileyen risk faktörünün fiyat riski gibi ekonomi temelli risklerin olduğunu belirtmiştir. Bununla birlikte çiftçilerin buğday üretiminde pazarlama ve teknoloji, finansal ve iklim, politikalardaki tutarsızlık ve destek yetersizliği, girdi fiyatı ve işgücü yetersizliği ile alt yapı ve don olayları gibi risk faktörleriyle karşı karşıya olduklarını saptamıştır. Aditto ve ark. (2012) Tayland'da 800 pirinç üreticisi ile yaptıkları araştırmada risk faktörlerini 6 başlık altında toplamış, ekonomik ve politik, iş ortamı, iklim, finansal, verim ve ürün fiyatı, girdi maliyetleri olarak isimlendirmişlerdir. 
Çizelge 1. Risk kaynakları tanımlayıcı istatistikleri ve rotasyon matrisi faktör yükleri

\begin{tabular}{|c|c|c|c|c|c|c|c|}
\hline \multirow[t]{2}{*}{ Risk Kaynakları } & \multirow[t]{2}{*}{ Ort. } & \multirow{2}{*}{$\begin{array}{c}\text { Std } \\
\text { Sapma }\end{array}$} & \multicolumn{5}{|c|}{ Bileşenler* } \\
\hline & & & 1 & 2 & 3 & 4 & 5 \\
\hline Yöreye uygun çeşit seçilmemesi & 3.29 & 1.71 & 0.900 & 0.022 & -0.003 & 0.019 & 0.058 \\
\hline Kalitesiz tohum veya fide seçimi & 3.34 & 1.49 & 0.868 & -0.016 & -0.149 & 0.177 & 0.006 \\
\hline $\begin{array}{l}\text { Sertifikalı tohum veya fide } \\
\text { kullanılmaması }\end{array}$ & 3.57 & 1.78 & 0.854 & 0.016 & -0.239 & 0.095 & 0.041 \\
\hline Ürün çeşitlendirmesinin yapılmaması & 3.03 & 1.63 & 0.747 & 0.041 & -0.087 & 0.036 & 0.109 \\
\hline Zamansız yağış (Hasattan önce) & 3.20 & 1.23 & 0.722 & 0.141 & 0.263 & -0.070 & 0.050 \\
\hline $\begin{array}{l}\text { Aile fertlerinin göç etmesi ve aile işgücü } \\
\text { yetersizliği }\end{array}$ & 3.27 & 1.44 & 0.716 & 0.187 & -0.062 & -0.091 & -0.038 \\
\hline $\begin{array}{l}\text { Kimyasal ilaç ve gübre kullanılmasında } \\
\text { bilgi eksikliği }\end{array}$ & 3.12 & 1.69 & 0.711 & 0.090 & 0.146 & 0.292 & -0.016 \\
\hline Kredi vadelerinin kısa olması & 2.83 & 1.69 & 0.080 & 0.938 & 0.038 & -0.001 & -0.043 \\
\hline Kredi kaynaklarının yetersizliği & 2.80 & 1.63 & 0.066 & 0.928 & -0.052 & 0.080 & -0.111 \\
\hline Yabancı sermaye bulamama & 2.65 & 1.59 & 0.123 & 0.859 & -0.237 & 0.063 & 0.107 \\
\hline Öz sermaye yetersizliği & 2.54 & 1.59 & 0.154 & 0.855 & -0.278 & -0.030 & 0.136 \\
\hline Hastalıklardan dolayı verim düşüklüğü & 4.08 & 1.29 & 0.032 & -0.303 & 0.822 & -0.014 & 0.148 \\
\hline Zararlılardan dolayı verim düşüklüğü & 4.18 & 1.18 & 0.089 & -0.312 & 0.814 & -0.010 & 0.151 \\
\hline Girdi maliyetlerinin yüksek olması & 4.55 & 0.95 & -0.097 & 0.007 & 0.689 & -0.140 & -0.118 \\
\hline Enflasyonun yüksek olması & 4.42 & 1.00 & -0.120 & 0.012 & 0.619 & -0.228 & 0.022 \\
\hline Uygun arazi koşullarının olmaması & 2.68 & 1.53 & -0.091 & -0.190 & 0.078 & 0.846 & -0.037 \\
\hline Teknik bilgi ve danışman eksikliği & 2.44 & 1.51 & 0.295 & -0.089 & -0.222 & 0.840 & 0.105 \\
\hline Üretim alanının yetersiz olması & 2.65 & 1.46 & 0.240 & 0.233 & -0.188 & 0.805 & -0.022 \\
\hline Nakliye sırasında ürün kaybı & 2.49 & 1.51 & -0.069 & 0.303 & -0.271 & 0.633 & -0.118 \\
\hline Don & 3.46 & 1.39 & -0.026 & -0.057 & 0.169 & -0.222 & 0.846 \\
\hline Kar & 2.34 & 1.37 & -0.067 & 0.103 & -0.290 & 0.180 & 0.731 \\
\hline Dolu & 3.86 & 1.06 & 0.271 & 0.005 & 0.220 & -0.007 & 0.709 \\
\hline Açıklanan Toplam Varyans (\%) & & & 21.41 & 16.68 & 12.906 & 12.615 & 8.656 \\
\hline Açıklanan Birikimli Toplam Varyans (\%) & & & 21.41 & 38.09 & 51.002 & 63.617 & 72.273 \\
\hline Barlett's Testi & \multicolumn{3}{|c|}{$X^{2}: 1914.84$} & \multicolumn{4}{|c|}{$p=0.000$} \\
\hline Kaiser-Meyer-Olkin & \multicolumn{3}{|c|}{0.73} & & & & \\
\hline Cronbach's Alpha & \multicolumn{3}{|c|}{0.78} & & & & \\
\hline
\end{tabular}

*1. Üretim ve Teknik Riskler, 2. Finansal Riskler, 3. Verim ve Maliyet Riskleri, 4. Pazarlama ve Altyapı Riskleri, 5. iklim Riskleri

Üreticiler bu risklerin etkisini azaltmak veya kısmen önlemek için risk stratejileri geliştirmekte ve uygulamaktadır. Çalışmada kullanılan risk stratejileri, araştırma alanı ve literatür dikkate alınarak 16 adet olarak belirlenmiştir. Veri setinin faktör analizine uygunluğunu belirlemek için uygulanan Kaiser-Meyer-Olkin ve Barlett testleri sonucunda KMO değeri 0.72 olarak hesaplanmış ve Barlett testi anlamlı bulunmuştur $(p=0.000)$. Buna göre veri setinin faktör analizi için uygun olduğu belirlenmiştir. Bununla birlikte güvenilirlik katsayısı olan Cronbach's alpha 0.78 olarak hesaplanmıştır. $\mathrm{Bu}$ değer modelin güvenilir olduğunu ve faktörler arasında pozitif bir ilişki olduğunu göstermektedir (Çizelge 2).

Faktör analizi sonucuna göre risk stratejileri 5 faktör altında toplanmıştır. Analiz sonucuna göre elde edilen 5 faktörün toplam varyansın \%73.64'ünü açıkladığı saptanmıştır. (Çizelge 2). Elde edilen faktör yükleri dikkate alınarak faktörler; "işletme Planlaması Yapmak", "Üretim Çeşitliliği ve Teknik Destek Sağlanması", "Yeniliklerin Benimsenmesi ve Pazar Bilgisi Edinmek", "işletme Büyüklüğünü ve Kapasitesini Değiştirmek" ve "Harcamalarda Tasarruf Yapmak" şeklinde adlandırılmıştır. 
Çizelge 2. Risk stratejileri tanımlayıcı istatistikleri ve rotasyon matrisi faktör yükleri

\begin{tabular}{|c|c|c|c|c|c|c|c|}
\hline \multirow[t]{2}{*}{ Risk Stratejileri } & \multirow[t]{2}{*}{ Ort. } & \multirow{2}{*}{$\begin{array}{c}\text { Std. } \\
\text { Sapma }\end{array}$} & \multicolumn{5}{|c|}{ Bileşenler* } \\
\hline & & & 1 & 2 & 3 & 4 & 5 \\
\hline İşletmede üretim planlaması yapmak & 4.35 & 1.08 & 0.885 & 0.242 & 0.228 & -0.106 & 0.077 \\
\hline İşletme kayıtlarını düzenli olarak tutmak & 4.33 & 1.08 & 0.879 & 0.151 & 0.286 & -0.102 & 0.149 \\
\hline Harcamaları planlamak & 4.42 & 1.03 & 0.869 & 0.179 & 0.065 & -0.120 & 0.144 \\
\hline Tarım danışmanlarıyla daha sık görüşmek & 3.83 & 1.48 & 0.105 & 0.868 & 0.040 & 0.079 & 0.160 \\
\hline Üretimle ilgili eğitimlere katılmak & 3.68 & 1.53 & 0.089 & 0.770 & 0.058 & 0.257 & 0.080 \\
\hline İşletmede birden çok ürün yetiştirmek & 4.21 & 1.23 & 0.213 & 0.765 & 0.033 & -0.131 & 0.154 \\
\hline Sertifikalı tohum ve fide kullanmak & 4.60 & 0.80 & 0.169 & 0.550 & 0.230 & 0.000 & -0.029 \\
\hline Mevcut kaynakları verimli kullanmak & 4.04 & 1.27 & 0.135 & -0.004 & 0.793 & -0.032 & 0.287 \\
\hline Pazar araştırması yapmak & 4.55 & 0.82 & 0.232 & 0.242 & 0.782 & -0.129 & 0.078 \\
\hline Alet makine kullanımı artırmak & 3.91 & 1.46 & 0.017 & -0.003 & 0.758 & 0.218 & 0.142 \\
\hline Yeni tarım tekniklerinin uygulanması & 4.13 & 1.03 & 0.345 & 0.234 & 0.578 & -0.060 & -0.049 \\
\hline Damla sulama sistemi kullanmak & 2.53 & 1.67 & 0.019 & -0.172 & 0.094 & 0.862 & -0.006 \\
\hline Arazi genişliğini değiştirmek & 2.53 & 1.55 & -0.161 & 0.227 & -0.243 & 0.822 & 0.041 \\
\hline İşletme kapasitesini artırmak & 2.76 & 1.65 & -0.182 & 0.158 & 0.117 & 0.776 & -0.090 \\
\hline Ailenin özel harcamalarını azaltmak & 3.46 & 1.39 & 0.092 & 0.057 & 0.174 & -0.087 & 0.898 \\
\hline Harcamalarda tasarruf yapmak & 4.03 & 1.19 & 0.219 & 0.294 & 0.202 & 0.049 & 0.812 \\
\hline Açıklanan Toplam Varyans (\%) & & & 16.93 & 16.60 & 15.62 & 13.91 & 10.57 \\
\hline Açıklanan Birikimli Toplam Varyans (\%) & & & 16.93 & 33.54 & 49.16 & 63.07 & 73.64 \\
\hline Barlett's Testi & \multicolumn{2}{|c|}{$X^{2}: 1070.50$} & & \multicolumn{4}{|c|}{$p=0.000$} \\
\hline Kaiser-Meyer-Olkin & \multicolumn{2}{|c|}{0.72} & & & & & \\
\hline Cronbach's Alpha & \multicolumn{2}{|c|}{0.78} & & & & & \\
\hline
\end{tabular}

*1. İşletme Planlaması Yapmak, 2. Üretim Çeşitliliği ve Teknik Destek, 3. Yeniliklerin Benimsenmesi ve Pazar Bilgisi Edinmek, 4. İşletme Büyüklüğünü ve Kapasitesini Değiştirmek, 5. Harcamalarda Tasarruf Yapmak

Üretimde karşılaşılan risklerin buğday gelirine etkisini ortaya koymak amacıyla çoklu regresyon analizi kullanılmıştır. Analiz için oluşturulan modelde buğday geliri bağımlı değişken olarak kullanılırken faktör analizinde elde edilen riskler bağımsız değişkenler olarak kullanılmıştır. Analiz sonucunda elde edilen $\mathrm{R}^{2}$ değeri 0.048 olarak hesaplanmıştır. $R^{2}$ değerinin düşük çıkması risk faktörlerinin üreticiden üreticiye farklı şekilde algılandığını ortaya koymaktadır (Meuwissen ve ark., 2001; Flaten ve ark., 2005; Aditto ve ark., 2012).

Modelde finansal riskler $(p=0.066)$ ile iklim riskleri ( $p=0.032$ ) istatistiki açıdan anlamlıdır. Analiz sonuçlarına göre iklim riskleri ve finansal risklerin buğday gelirini olumsuz yönde etkilediği saptanmıştır. Tarımsal üretimin doğal koşullara yüksek bağlılığı göz önüne alındığında, iklim riskleri dikkate alınması gereken ilk faktördür. Dolayısıyla üreticilerin iklim risklerini önlemesi mümkün olmadığı gibi bu riskleri tarım sigortası ya da sermayeyi artırmak gibi yollarla transfer etmeleri gerekmektedir. Ancak araştırma bölgesinde 18 üreticinin buğday için sigorta yaptırdığı belirlenmiştir. Bu sayı özellikle iklim risklerinin yoğun olarak karşılaşıldığı bölgede oldukça düşüktür. Daha önceden yapılmış çalışmalarda üreticilerin işletme kapasitesini artırıp nakit sermayeyi yükseltmek, ürün sigortası yaptırmak ve satışları sürece yaymak gibi risk stratejileri uyguladıkları belirlenmiştir (Ağır ve ark., 2015; Uçar ve Engindeniz, 2019; İkikat Tümer ve ark., 2019) (Çizelge 3). 
Çizelge 3. Risk faktörlerinin buğday gelirine etkisi

\begin{tabular}{lcrrr} 
& B & Beta & \multicolumn{1}{c}{ t } & p değeri \\
\hline Sabit & 21325.73 & & 13.880 & $0.000^{* * *}$ \\
Finansal Riskler & -2867.87 & $-0,166$ & -1.859 & $0.066^{*}$ \\
Pazarlama ve Altyapı Riskleri & -2080.39 & $-0,121$ & -1.348 & 0.180 \\
Üretim ve Teknik Riskler & 1461.11 & 0,085 & 0.947 & 0.346 \\
Düşük Verim ve Maliyet Riskleri & -443.909 & $-0,026$ & -0.288 & 0.774 \\
İklim Riskleri & -3352.72 & $-0,194$ & -2.173 & $0.032^{* *}$ \\
\hline
\end{tabular}

${ }^{*} \mathrm{p}<0.1 * * \mathrm{p}<0.05, \mathrm{R}^{2}=0.048, \mathrm{p}=0.060, \mathrm{~F}=2.195$

Buğday üretiminde riskle mücadele için üreticilerin uyguladıkları stratejiler ile bazı sosyodemografik özellikler ve risk faktörleri arasındaki ilişkileri incelemek beş ayrı regresyon analizi uygulanmış olup, bu beş model istatistiksel olarak anlamlı bulunmuştur (Çizelge 4). Analiz sonuçlarına göre ailedeki birey sayısı, finansal riskler ve üretimle ilgili teknik riskler işletme planlamasına yönelik algılarını negatif yönlü etkilemektedir. Bunun yanında düşük verim ve maliyet riskleri üreticilerin işletme planlaması algılarını olumlu etkilemektedir ( $p=0.007)$. Bu sonuçlara göre üretim maliyetlerinin yüksek olması üreticilerin üretimi çeşitlendirmelerini olumsuz yönde etkilemektedir. Bununla birlikte ailedeki birey sayısının artması üretime ayrılan bütçenin daha az olmasına neden olmaktadır.

Üretim çeşitliliği ve teknik destek sağlanması stratejisi, yıllık geliri yüksek, daha tecrübeli üreticiler tarafından daha önemli olarak algılanmıştır. Bu durum gelir arttıkça işletmelerdeki üretimin çeşitlendiğini ve tecrübeli üreticilerin risklere karşı daha etkin stratejiler geliştirdiklerini ortaya koymaktadır (Çizelge 4). Ayrıca, üreticiler üretim ve teknik riskler ve finansal risklerle karşılaştıkça üretim çeşitliliği ve teknik destek sağlanması stratejisini uygulamaktadırlar. Hayran (2019), çalışmasında üreticilerin tecrübelerindeki artışın risklere karşı üretimde çeşitlilik stratejisini uygulamalarında pozitif etki yaptığını belirlemiştir.

Çizelge 4'e göre, üreticilerin yeniliklerin benimsenmesi ve pazar bilgisi edinmek stratejisi algıları üzerinde üretici geliri ile düşük verim ve maliyet riski arasında pozitif ve anlamlı bir ilişki olduğu belirlenmiştir. Buna göre yüksek gelire sahip üreticilerin yeniliklerin benimsenmesi ve pazar bilgisi edinme stratejisine daha olumlu baktıkları söylenebilir. Ayrıca düşük verim ve yüksek maliyetler de söz konusu stratejiyi olumlu yönde etkilemektedir. Yüksek gelirli üreticiler pazar araştırması yapmakta ve ayrıca yeniliklerin benimsenmesine daha açık oldukları görülmektedir. Üreticilerin bu tutumu bölgedeki tarımsal yayım faaliyetlerinin artırılmasının gerekli olduğunu ortaya koymaktadır. Böylelikle diğer üreticilerin de bu faaliyetlerden yararlanması sağlanarak üretimde karşılaştıkları risklere yönelik atılacak adımlar ile üretimde verim ve kalite sağlanabilir.

Üreticiler işletme büyüklüğü ve kapasitesini değiştirme stratejisi algıları ile tarım dışı gelir, tarımsal örgütlere üyelik durumu ve finansal riskler arasında negatif yönlü ve istatistiksel olarak anlamlı bir ilişki olduğu, iklim riskleri ile pozitif yönlü bir ilişki olduğu sonucuna ulaşılmıştır. Buna göre, herhangi bir tarımsal örgüte üye, tarım dışı gelire sahip ve üretimde finansal riskleri önemli olarak algılayan üreticiler işletme büyüklüğü ve kapasitesini değiştirme stratejisini daha olumsuz değerlendirmektedirler. Flaten ve ark. (2004) yaptıkları çalışmada, tarım dışı gelirin üretimde çeşitlilik stratejisi üzerinde etkili olduğunu belirlemişlerdir. Elde edilen sonuçlar değerlendirildiğinde tarım dışı gelire sahip üreticilerin daha az risk almalarından dolayı işletme kapasitesi değişimine gitmeye istekli değillerdir.

Üreticilerin risklere karşı harcamalarda tasarruf yapma stratejisi algıları ile tarımsal örgütlere üyelik ve pazarlama ile alt yapı riskleri arasında istatistiksel olarak anlamlı ve ters yönlü ilişki saptanırken, düşük verim ve maliyet riskleri ile pozitif ve istatistiksel olarak anlamlı bir ilişki olduğu saptanmıştır (Çizelge 4). Düşük verim ve maliyet risk algısı yüksek olan üreticiler harcamalarında tasarruf yaparak bu riski azaltmaya yönelik önlem almaya çalışmaktadırlar. Aditto ve ark. (2012) küçük ölçekli işletmelerin risk algısını araştırdıkları çalışmalarında üreticilerin eğitim seviyesinin arttıkça risk stratejilerini uygulama bilincinin de arttığını dolayısıyla eğitimli üreticilerin eğitim seviyesi düşük üreticilere göre işletme yönetiminde daha etkin olduklarını belirtmişlerdir. Ayrıca pazarlama yönetimi ve tarım dışı gelir stratejilerinin kredilerden faydalanan üreticiler için önemsiz olduğunu belirlemişlerdir. 
Çizelge 4. Risk yönetim stratejileri çoklu regresyon analizi sonuçları

\begin{tabular}{|c|c|c|c|c|c|}
\hline & \multicolumn{5}{|c|}{ Risk Stratejileri } \\
\hline & $\begin{array}{l}\text { Işletme } \\
\text { Planlaması } \\
\text { Yapmak }\end{array}$ & $\begin{array}{c}\text { Üretim } \\
\text { Çeşitliliği ve } \\
\text { Teknik } \\
\text { Destek } \\
\text { Sağlanması }\end{array}$ & $\begin{array}{c}\text { Yeniliklerin } \\
\text { Benimsenmesi } \\
\text { ve Pazar Bilgisi } \\
\text { Edinmek }\end{array}$ & $\begin{array}{c}\text { İşletme } \\
\text { Büyüklüğünü } \\
\text { ve Kapasitesini } \\
\text { Değiştirmek }\end{array}$ & $\begin{array}{c}\text { Harcamalarda } \\
\text { Tasarruf } \\
\text { Yapmak }\end{array}$ \\
\hline Sabit & -1.979 & -5.620 & -2.467 & 1.162 & 0.508 \\
\hline Log-Yıllık Gelir & 0.238 & $0.347^{* *}$ & $0.281^{*}$ & -0.030 & -0.157 \\
\hline Log-Mesafe & -0.057 & 0.119 & 0.003 & 0.026 & 0.101 \\
\hline Log-Tecrübe & 0.081 & $0.694 * *$ & -0.015 & 0.013 & 0.374 \\
\hline Tarım Dışı Gelir & 0.085 & -0.324 & -0.037 & $-0.586 * *$ & -0.155 \\
\hline Tarımsal Örgütlere Üyelik & 0.041 & -0.084 & 0.082 & $-0.507^{*}$ & $-0.473^{*}$ \\
\hline Ailedeki Birey Sayısı & $-0.092 *$ & -0.028 & -0.041 & -0.013 & -0.010 \\
\hline İşletme Büyüklüğü & -0.002 & -0.002 & -0.002 & 0.000 & 0.000 \\
\hline Finansal Riskler & $-0.206 * *$ & $0.212 * *$ & -0.039 & $-0.269 * *$ & 0.020 \\
\hline $\begin{array}{l}\text { Pazarlama ve Altyapı } \\
\text { Riskleri }\end{array}$ & -0.201 & $-0.235^{* *}$ & -0.026 & -0.023 & $-0.212 * *$ \\
\hline $\begin{array}{l}\text { Düşük Verim ve Maliyet } \\
\text { Riskleri }\end{array}$ & $0.239 * *$ & 0.019 & $0.332 * * *$ & -0.137 & $0.283 * *$ \\
\hline İklim Riskleri & 0.007 & -0.034 & 0.017 & $0.165^{*}$ & 0.116 \\
\hline Üretim ve Teknik Riskler & $-0.196 * *$ & $0.190 * *$ & 0.024 & -0.006 & -0.093 \\
\hline Düzeltilmiş $\mathrm{R}^{2}$ & $0.197^{* * *}$ & $0.231 * * *$ & $0.077^{*}$ & $0.121 * *$ & $0.113 * *$ \\
\hline $\mathrm{F}$ & 3.431 & 3.980 & 1.832 & 2.358 & 2.268 \\
\hline
\end{tabular}

${ }^{*} p<0.1 * * p<0.05 * * * p<0.01$

\section{Sonuç ve Öneriler}

Tarım sektörü doğa koşullarına bağlılığından ötürü riskten kaçınılması en zor sektördür. Üretimdeki kalite ve verimin korunması için bu risklerin belirlenmesi ve onlardan kaçınmak veya onların transfer edilmesi gerekmektedir. Bu yüzden üreticinin riskleri algılamasını ve bunlarla mücadelesini konu alan çalışmaların yapılması büyük önem taşımaktadır. Bu doğrultuda bu çalışmada Kahramanmaraş ili merkez ilçelerinde buğday üretimi yapan işletmelerin karşılaştıkları riskler ve risk stratejileri belirlenmiştir. Bunun yanında risk faktörlerinin üreticilerin buğday geliri üzerine etkisi incelenmiştir. Ayrıca üreticilere ait bazı sosyo-demografik özellikleri ve risk faktörleri ile risk stratejileri arasındaki ilişki saptanmıştır.

Elde edilen sonuçlara göre üreticilerin karşılaştıkları risk faktörleri; üretim ve teknik riskler, finansal riskler, pazarlama ve altyapı riskleri, düşük verim ve maliyet riskleri ile iklim riskidir. Üreticiler bu risklerden korunmak amacıyla işletme planlaması yapmak, üretimde çeşitliliğe gidilmesi ve teknik destek sağlanması, yeniliklerin benimsenmesi ve pazar bilgisi edinmek, işletme büyüklüğü/işletme kapasitesini değiştirmek ve harcama planlaması yapmak stratejilerini uygulamaktadırlar.

Finansal riskler ve iklim risklerinin üreticilerin buğday üretiminden elde ettikleri gelirlerini olumsuz etkilediği belirlenmiştir. Bununla birlikte yıllık gelir, tarımsal üretimdeki tecrübe, tarım dışı gelir, üretici örgütlerine üyelik durumu ve ailedeki birey sayısı gibi sosyo-demografik özellikler ve üretimde karşılaşılan finansal riskler, pazarlama ve altyapı riskleri, düşük verim ve maliyet riskleri, iklim riskleri, üretim ve teknik riskler gibi faktör risk stratejilerinin uygulanmasını etkilemektedir.

Bu bilgiler ışığında politika yapıcıların iklim ve finansal risklerin üretim üzerindeki etkisini azaltmaya yönelik stratejiler geliştirmeleri ve uygulamaları önemlidir. Finansal risklerin buğday gelirine olumsuz etkisi göz önünde bulundurulduğunda destek ve kredi miktarlarının artırılması ve bu kaynaklara ulaşımın kolaylaştırılmasına yönelik politikalar geliştirilmesi önemlidir. İklim risklerine karşı ise üreticilerin tarım sigortası (bitkisel üretim sigortası ve köy bazlı kuraklık sigortası) yaptırmaları konusunda bilinçlendirilmesi ve teşvik edilmesi gerekmektedir. Yüksek gelire sahip üreticilerin yeniliklerin benimsenmesine yönelik daha istekli olmaları göz önüne alındığında tarımsal yayım faaliyetlerinin artırılması ve bu üreticilerin diğer üreticileri de teşvik etmesine yönelik adımlar atılması önemlidir. Çıkar Çatışması Beyanı: Makale yazarları arasında herhangi bir çıkar çatışması bulunmamaktadır.

Araştırmacıların Katkı Oranı Beyan Özeti: Yazarlar makaleye eşit oranda katkı sağlamışlardır. 


\section{Kaynaklar}

Aditto, S., Gan, C. ve Nartea, G. 2012. Sources of risk and risk management strategies: The case of smallholder farmers in a developing economy. http://dx.doi.org/10.5772/50392

Ağır, H. B., Saner, G. ve Adanacıoğlu, H. 2015. Risk sources encountered by farmers in the open field production of strawberry and risk management strategies: $A$ case of Menemen-Emiralem District of İzmir. Journal of Agricultural Sciences, 21(1): 1325.

Akçaöz, H., Özkan, B. ve Kızılay, H. 2006. Antalya ilinde tarımsal üretimde risk yönetimi ve tarım sigortası uygulamaları. Tekirdağ Ziraat Fakültesi Dergisi, 3(2): 93-103.

Bayramoğlu, Z., Kaya, S. ve Karakayacı Z. 2013. Tarım işletmelerinde risk kaynakları ve risk yönetim stratejilerinin belirlenmesi: Çumra İlçesi Örneği. Selçuk Tarım ve Gıda Bilimleri Dergisi, 27(1): 46-54.

Büyüköztürk, Ş. 2002. Faktör analizi: Temel kavramlar ve ölçek geliştirmede kullanımı. Kuram ve Uygulamada Eğitim Yönetimi Dergisi, 8(4): 470-483.

Çolakoğlu, Ö. M. ve Büyükekşi, C. 2014. Açımlayıcı faktör analiz sürecini etkileyen unsurların değerlendirilmesi. Karaelmas Journal of Educational Sciences, 2(1): 58-64.

Flaten, O., Lien, G., Koesling, M., Valle, P. S. ve Ebbesvik, M. 2005. Comparing risk perceptions and risk management in organic and conventional dairy farming: Empirical results from Norway. Livestock Production Science, 95(1-2): 11-25.

Hayran, S. (2019). Perceptions of wheat producers towards risk and risk management strategies: A case from Turkey. Ciência Rural, 49

(12). https://doi.org/10.1590/0103$8478 c r 20190396$

Hazneci E. ve Ceyhan V., 2011. Amasya ili Merzifon illçesinde süt sığırcılığı yapan tarım işletmelerinde risk analizi. Akdeniz Üniversitesi Ziraat Fakültesi Dergisi, 24 (2): 109-114.
Ikikat Tümer, E., Birinci A. ve Aksoy A. 2010. Çiftçilerin sosyo-ekonomik özelliklerinin kümeleme analiziyle belirlenmesi: Erzurum ìli örneği. Atatürk Üniversitesi Ziraat Fakültesi Dergisi, 41(1): 29-37.

İkikat Tümer, E., Ağır, H. B. ve Uslu, Z. 2019. Çiftçilerin tarım sigortası yaptırma istekliliği: Konya İli Ilgın İlçesi örneği. KSÜ Tarım ve Doğa Dergisi, 22 (4): 571-576.

Meuwissen, M. P., Huirne, R. B. M. ve Hardaker, J. B. 2001. Risk and risk management: An empirical analysis of dutch livestock farmers. Livestock Production Science, 69 (1): 43-53.

Naseri, Z. ve Saner, G. 2017. Uşak ilinde buğday üreticilerinin olası kuraklık sigortasını benimsemesinde etkili olan faktörlerin analizi. Balkan ve Yakın Doğu Sosyal Bilimler Dergisi, 03 (02): 169-180.

Newbold, P. 1995. Statistics for Business and Economics. Prentice-Hall, New Jersey.

Özsayın, D. ve Çetin, B. 2004. Hayvan sigortası yaptırmış işletmelerde risk ve risk yönetimi algılamaları. Türkiye VI. Tarım Ekonomisi Kongresi, 16-18 Eylül, Tokat, s. 197-200.

Theuvsen, L. 2013. Risks and risk management in agriculture. Problems of World Agriculture/Problemy Rolnictwa Światowego. 13 (4): 162-174.

Uçar, K. ve Engindeniz S. 2019. Malatya ilinde kayısı üretiminde karşılaşılan risk kaynakları ve uygulanabilecek risk yönetimi stratejileri. Iğdır Üniversitesi Fen Bilimleri Enstitüsü Dergisi, 9 (4): 2313-2320.

Vuruş Akçaöz, H. ve Akdemir, Ş. 2001. Tarımsal üretimde risk, risk analizi ve risk davranışları: Çukurova Bölgesi uygulamaları. Akdeniz Üniversitesi Ziraat Fakültesi Dergisi, 14 (1): 107-118.

Vuruş Akçaöz, H. ve Özkan, B. 2002. Tarımsal üretimde karşılaşılan riskler ve uygulanabilecek stratejiler. Türkiye V. Tarım Ekonomisi Kongresi, 18-20 Eylül, Erzurum, s. 77-83. 